\title{
AIRCRAFT TURBINE ENGINE AUTOMATIC CONTROL BASED ON ADAPTIVE DYNAMIC MODELS
}

\author{
Sergiy Yepifanov \\ Department of Aircraft Engine Design, Faculty of Aviation Engines, National Aerospace University \\ "Kharkiv Aviation Institute", 17 Chkalova St., Kharkiv, Ukraine \\ s.yepifanov@khai.edu•ORCID: 0000-0003-0533-9524
}

\begin{abstract}
One of the most perspective development directions of the aircraft engine is the application of adaptive digital automatic control systems (ACS). The significant element of the adaptation is the correction of mathematical models of both engine and its executive, measuring devices. These models help to solve tasks of control and are a combination of static models and dynamic models, as static models describe relations between parameters at steady-state modes, and dynamic ones characterize deviations of the parameters from static values.

The work considers problems of the models' correction using parametric identification methods. It is shown that the main problem of the precise engine simulation is the correction of the static model. A robust procedure that is based on a wide application of a priori information about performances of the engine and its measuring system is proposed for this purpose. One of many variants of this procedure provides an application of the non-linear thermodynamic model of the working process and estimation of individual corrections to the engine components' characteristics with further substitution of the thermodynamic model by approximating on-board static model. Physically grounded estimates are obtained based on a priori information setting about the estimated parameters and engine performances, using fuzzy sets.

Executive devices (actuators) and the most inertial temperature sensors require correction to their dynamic models. Researches showed, in case that the data for identification are collected during regular operation of ACS, the estimates of dynamic model parameters can be strongly correlated that reasons inadmissible errors.

The reason is inside the substantial limitations on transients' intensity that contain regular algorithms of acceleration/deceleration control. Therefore, test actions on the engine are required. Their character and minimum composition are determined using the derived relations between errors in model coefficients, measurement process, and control action parameters.
\end{abstract}

Keywords: turbine engine, automatic control, model, adaptation. 


\section{INTRODUCTION}

Aircraft engine is a multi-mode object that operates is a wide range of flight conditions. The current development trends of the turbine engine are inseparably related to the intensification of the thermodynamic cycle (increasing turbine inlet temperature and compressor pressure ratio) and life-time extension.

One of the main directions of aircraft engine perfection relies on the development of the automatic control systems (ACS). Progress in the on-board electronics stimulated the implementation of the FADEC (Full Authority Digital Electronic Control) in the turbine industry. Currently, concepts of "smart engine", "distributed control", "integrated control" and principles of model-based control are of great scientific and engineering interest and going through rapid development.

Taking into account the above-mentioned features of the turbine engine, we can say that the engine control can be improved by the ACS adaptation to continuously changed operation conditions. In a general case, this is ensured by the introduction of additional feedbacks into the system, which transforms information about the operation conditions into the adjustment of the controlling device.

The general structure of the adaptive ACS is shown in Fig. 1. The following nomenclature is introduced:

$\vec{U} \quad$ - engine control actions;

$\vec{F} \quad$ - engine external actions;

$\vec{Y} \quad$ - engine measured parameters;

$\vec{Z} \quad$ - engine unmeasured parameters;

$\vec{F}_{1} \quad$ - engine external actions that are used to form set values of the controlled parameters;

$\vec{F}_{2} \quad$ - engine external actions that are used for adaptation;

$\Delta \vec{Y}$ - deviations of the measured values from the set values;

$\vec{\alpha}_{1} \quad-$ setting actions;

$\vec{Y}_{\text {set }}-$ set values of the engine parameters;

$\vec{R} \quad$ - actuator's control action;

$\vec{Q} \quad$ - correction action on the controller.

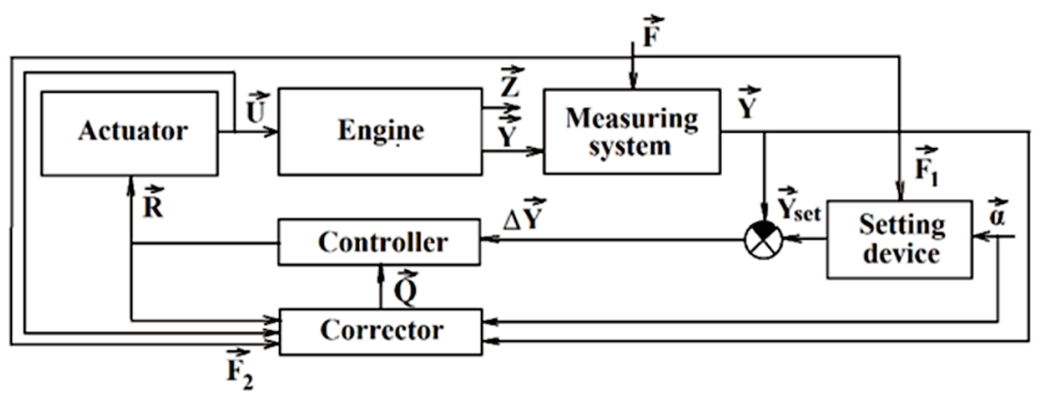

Fig. 1. Structure of adaptive ASC. 
The adaptive ACS are classified in many ways $[1,2]$. In this paper, the main attention is paid to the operation conditions, changes of which are the main reason for the adaptation.

The analysis shows the following conditions (each of them, as a rule, has its own adaptation feedback):

- engine operation mode;

- altitude, velocity, and climatic conditions;

- engine individual features;

- $\quad$ engine technical state;

- $\quad$ individual features of actuators;

- $\quad$ actuators technical state;

- $\quad$ technical state of the measuring system.

Effectiveness of the correction depends on how accurately we know the changes in operational conditions and technical state, as well as the structure and relations between parameters of elements in the system. Information about this structure and relations should be contained in the mathematical models of the ASC and its elements.

Therefore, the models are an efficient tool that can be used not only during the ACS designing but also in the direct integration into control algorithms, which includes the adaptation function.

This paper considers the previously listed directions of adaptation and some problems of dynamic models application in their realization.

\section{MATHEMATICAL MODEL OF TWO-SPOOL TURBOFAN}

The base mathematical model of the engine has been formed on characteristics of the engine components and thermodynamic equations that describe conditions of their common operation [3]. It takes into account the influence of the working fluid composition and the temperature on the fluid thermophysical properties, simulates dynamics of rotors, gas volumes of the gas path, heat exchange, and tip clearances variation. The considered tasks of adaptive control can be solved, taking into account only rotor dynamics. However, even in this simplified case, the model is too complex and labor-intensive to be used in real-time control algorithms [4].

To develop a high-speed model, the base thermodynamic model is divided into two parts: static and dynamic. The static model calculates the engine parameters for the steady-state modes, and the dynamic model determines the deviations of the parameters from their static values. These deviations correspond to the transient modes. In the previously mentioned nomenclature, the static model has the form:

$\vec{Y}_{s t}=f(\vec{U}, \vec{F})$

where $\vec{Y}_{s t}$ - values of the parameters determined by the input $\vec{U}$ and $\vec{F}$ for a steady-state mode.

The dynamic model in the state space is expressed as:

$$
\begin{aligned}
& \dot{\vec{X}}=A \Delta \vec{X}+B \Delta \vec{U}+E \Delta \vec{F} \\
& \Delta \vec{Y}=C \Delta \vec{X}+D \Delta \vec{U}+G \Delta \vec{F}
\end{aligned}
$$

Where $\dot{\vec{X}}$ - rotation speeds of rotors, $\vec{Y}$ - other engine parameters, $\Delta-$ deviation from the static value. 
Hence, the values of parameters for transient modes are determined as:

$\vec{X}=\vec{X}_{s t}+\Delta \vec{X} ; \vec{Y}=\vec{Y}_{s t}+\Delta \vec{Y}$

As an example, consider a two-spool turbofan, whose scheme is shown in Fig. 2.

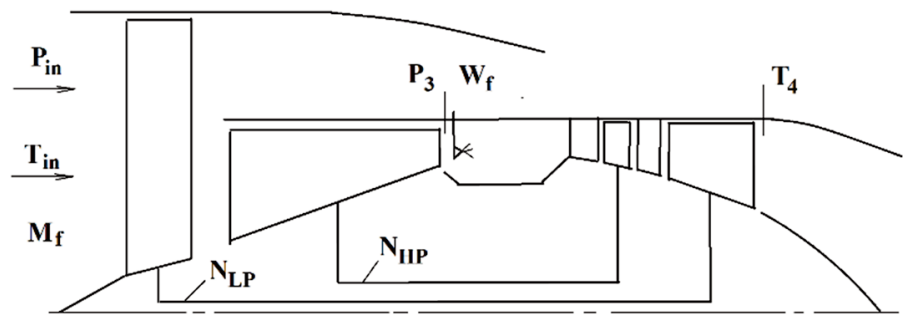

Fig. 2. Scheme of two-spool turbofan.

The input parameters are fuel flow $W_{f}$ and parameters of the air at the intake including pressure $P_{i n}$, temperature $T_{i n}$ and Mach number $M_{f}$ The output parameters are rotor speeds $N_{H P}, N_{L P}$, compressor discharge pressure $P_{3}$ and turbine discharge temperature $T_{4}$. Hence, for this engine:

$\vec{X}=\left[\begin{array}{c}N_{L P} \\ N_{H P}\end{array}\right] ; \vec{Y}=\left[\begin{array}{c}P_{3} \\ T_{4}\end{array}\right] ; \vec{U}=W_{f} ; \vec{F}=\left[\begin{array}{l}P_{i n} \\ T_{i n} \\ M_{f}\end{array}\right]$

The structure of the mathematical model is shown in Fig. 3.

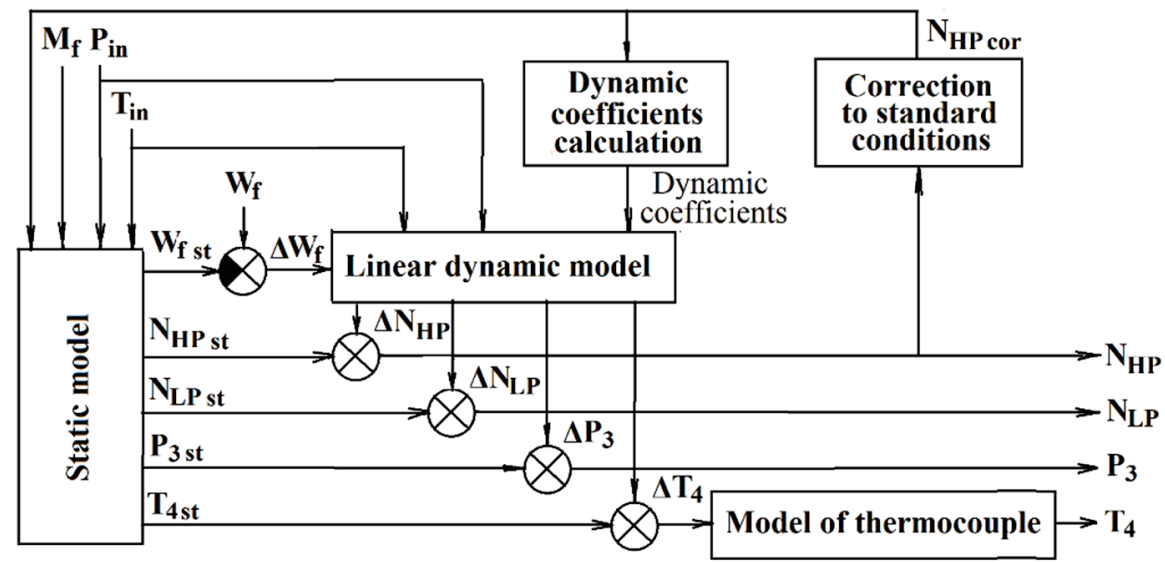

Fig. 3. Structure of the engine dynamic model.

\section{ADAPTATION TO EXTERNAL CONDITIONS VARIATION}

The influence of parameters $P_{\text {in }}$ and $T_{\text {in }}$ in the static model is well described by the well-known correction formulas from the engine theory $[5,6]$. The influence of Mach number is taken into account by additional corrections that are determined experimentally [7]. The operation mode in the model (1) can be set by any of the parameters $\vec{U}, \vec{Y}$ : for example, by the rotational speed of the high-pressure rotor. 
The static model, in this case, is expressed as:

$$
N_{L P, c o r}=f\left(N_{H P, c o r}\right) C L P\left(M_{f}\right) ; P_{3, c o r}=f\left(N_{H P, c o r}\right) C_{P}\left(M_{f}\right) ; T_{4, c o r}=f\left(N_{H P, c o r}\right) C_{T}\left(M_{f}\right),
$$

where: $C_{L P}, C_{P}, C_{T}-$ coefficients of correction by the flight velocity;

$$
N_{H P, c o r}=N_{H P} \sqrt{\frac{T_{0}}{T_{i n}}} ; N_{L P, c o r}=N_{L P} \sqrt{\frac{T_{0}}{T_{i n}}} ; P_{3, c o r}=P_{3} \frac{P_{0}}{P_{i n}} ; T_{4, c o r}=T_{4} \frac{T_{0}}{T_{i n}} .
$$

Influence of parameters $P_{\text {in }}$ and $T_{\text {in }}$ on coefficients of the linear dynamic model (elements of matrices A, B, C, D, E, G) can also be taken into account using similarity of operation modes and the correction formulas [8]. In this case, we can exclude these parameters from vector $\vec{F}$, and the last additives of the equations (2) and (3) will express the influence of other input actions ( e.g., the air and power bleeding).

\section{ADAPTATION TO OPERATION MODE VARIATION}

In fact, we have explained the influence of the operation mode on the static model, which is represented by functions $f\left(N_{H P}\right.$ cor $)$ as the engine part-load performances.

The mode also significantly influences the coefficients of the linear dynamic model. In a range from idle to maximum thrust mode, their values may vary tens of times; the changes of sign are also possible.

The coefficients are calculated using the base thermodynamic model [3]. However, a very unpleasant phenomenon originates in the finite-linear presentation of characteristics of compressor, turbine, and other components in this model, values of the dynamic coefficients have a significant scatter, and some of them have no physical sense (see Fig. 4).

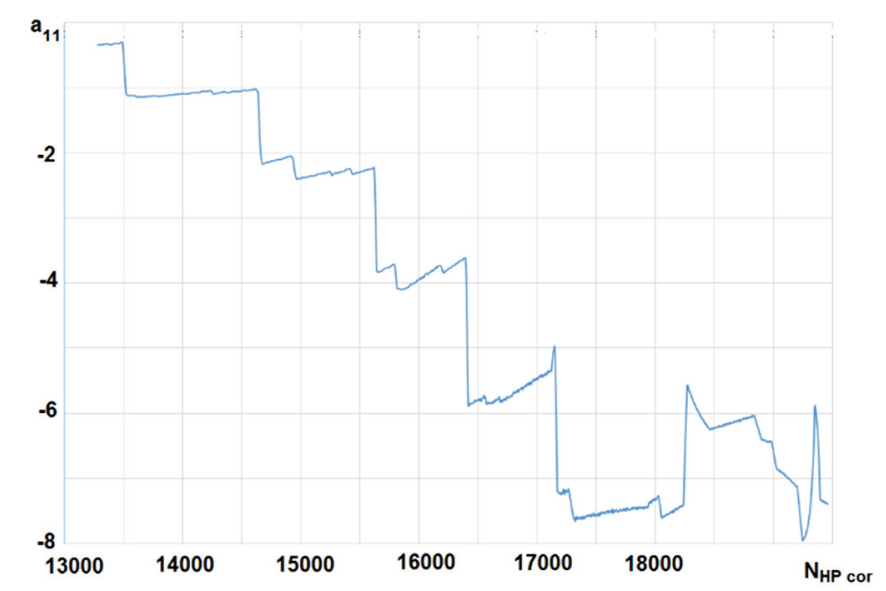

Fig. 4. Coefficient $\mathrm{a}_{11}$ of the linear dynamic model calculated by the base thermodynamic model versus operation mode.

Therefore, there is a necessity of smoothing the relation of these coefficients on the operation mode. In paper [9], we showed that the strictly conventional application of the smoothing could result in the formation of an unstable model. Therefore, the following method has been proposed [10]. At the first step, the linear dynamic model in the state-space is transformed into a set of transfer functions. For the considered engine with fuel flow rate as the input parameter, the transfer functions are: 
$W_{H P}(s)=\frac{K_{N_{H P}}\left(\tau_{H P} s+1\right)}{T_{1} T_{2} s^{2}+\left(T_{1}+T_{2}\right) s+1} ; W_{L P}(s)=\frac{K_{N_{L P}}\left(\tau_{L P} s+1\right)}{T_{1} T_{2} s^{2}+\left(T_{1}+T_{2}\right) s+1} ;$

$W_{p_{3}}(s)=\frac{K_{p_{3}}\left(\tau_{P_{3}}^{2} s^{2}+\tau_{p_{3}} s+1\right)}{T_{1} T_{2} s^{2}+\left(T_{1}+T_{2}\right) s+1} ; W_{T_{4}}(s)=\frac{K_{T_{4}}\left(\tau_{T_{4}}^{2} s^{2}+\tau_{T_{4}} s+1\right)}{T_{1} T_{2} s^{2}+\left(T_{1}+T_{2}\right) s+1}$.

The Coefficients of these transfer functions have a clear physical meaning. For example, $T_{1}$ and $T_{2}$ are the time constants of rotors. $K_{N_{H P}}, K_{N_{L P}}, K_{P_{3}}$ and $K_{T_{4}}$ are amplification coefficients; they can be obtained from the engine static performances, which is an element of coordination between static and dynamic components of the engine model.

At the next step, according to the proposed method, the smoothing is applied to the coefficients of the transfer functions, and then an inverse transformation of the model can be done to transform it back into the state-space description.

\section{ADAPTATION TO ENGINE INDIVIDUAL FEATURES AND TECHNICAL STATE VARIATION}

The general methodical base for this type of adaptation is methods of identification. The difference is that the individual properties can be determined at an initial period of maintenance or by results of a factory test, and the proper corrections in ACS can be done before maintenance.

Variation of the technical state influences the characteristics of the engine components. First of all, this changes the static performances of the engine. Therefore, this adaptation direction concentrates on the correction of the static model. With this purpose, correcting parameters $\vec{\theta}$ are introduced into the model (1) and the static model has the following form:

$\vec{Y}_{s t}=f(\vec{U}, \vec{F}, \vec{\theta})$.

We developed an approach to the determination of the parameters in need for correction [11] based on the Least Square Method. To improve its robustness, this method is modified by combining the traditional function of empirical risk:

$\Phi_{e}(\vec{\theta})=\sum_{i=1}^{m} w_{i} \sum_{j=1}^{N}\left[y_{i j}-y_{i \bmod }\left(\vec{U}_{j}, \vec{F}_{j}, \vec{\theta}\right)\right]$

with the function of a priori risk:

$\Phi_{a}(\vec{\theta})=\sum_{q=1}^{Q} \alpha_{q} \Phi_{a q}(\vec{\theta})$,

where:

$w_{i}=\frac{1}{\sigma_{i}^{2}}-$ weight coefficients that take into account a difference in measuring errors,

$\sigma_{i}^{2}$ - dispersion of the $i$-th parameter,

$y_{i j}$ - value of $i$-th parameter measured at $j$-th mode,

$y_{i \bmod }$ - value of $\boldsymbol{i}$-th parameter calculated by the model, 
$\alpha_{q}$ - weight coefficient of the a priori information,

$\Phi_{a q}(\vec{\theta})$ - partial a priori risk function.

The proposed estimation procedure is shown in Fig. 5 and described in the paper [11] in application to a problem of the engine technical state analysis. It is also applicable for determining the best estimates of parameters $\vec{\theta}$ for the model (1) correction.

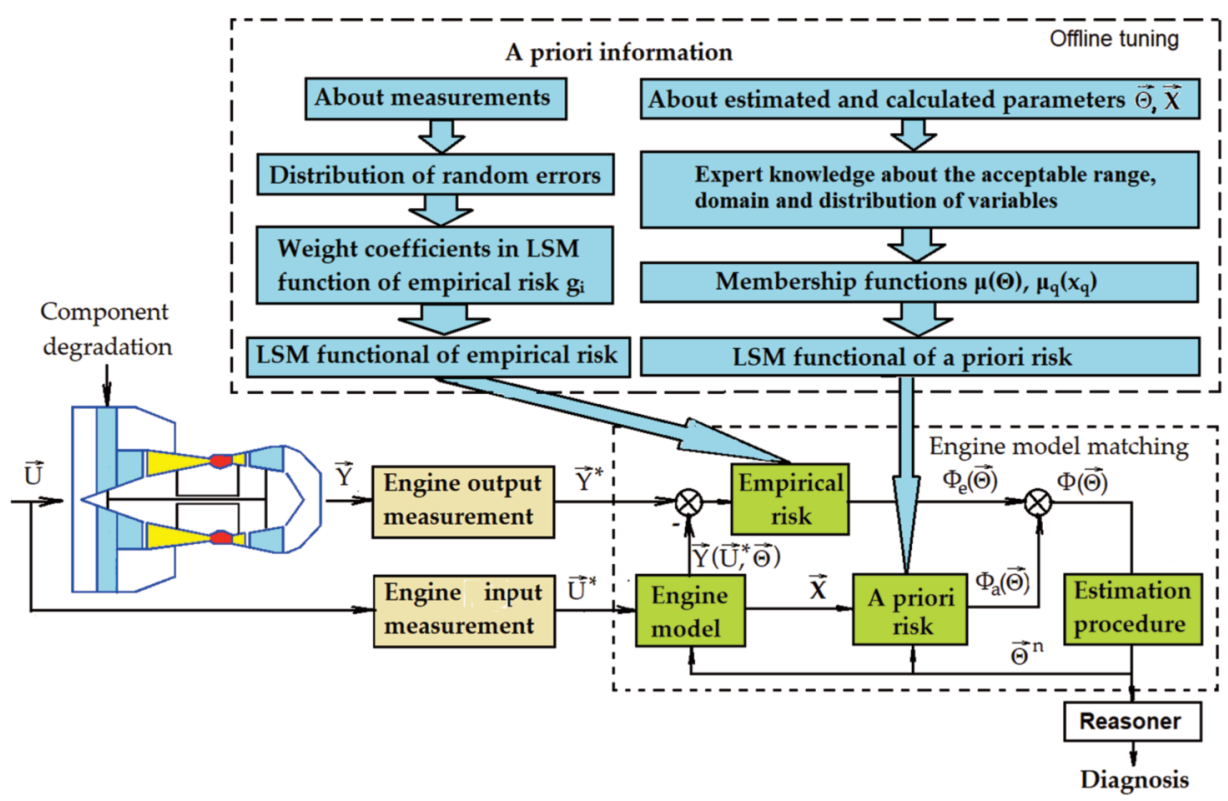

Fig. 5. Regularized multi-criteria identification of gas-turbine model.

The implementation of the a priori information about the correction parameters ensures the robustness of our proposed method. This information is set in the form of fuzzy sets with membership functions $\mu\left(\theta_{q}\right)$.

Then the partial a priori risk function is represented as [11]:

$\Phi_{a q}(\vec{\theta})=\frac{\int_{-\infty}^{\infty} \mu(x)\left(\theta_{q}-x\right)^{2} d x}{\int_{-\infty}^{\infty} \mu(x) d x}$

\section{ADAPTATION TO INDIVIDUAL FEATURES AND TECHNICAL STATE VARIATION OF ACTUATORS AND MEASURING SYSTEM}

Different from the engine adaptation, the actual correction problem of the actuators focuses more on its dynamic characteristics than the static ones. In literature [1], this problem is recommended to solve at the stage of ACS designing and development. However, this approach supposes that the serial production and maintenance stage provides full reproducibility, repeatability, and stability of dynamic performances of the equipment. This condition is not always satisfied since the engine is a complicated 
assembly that includes itself with many subsystems and numerous units whose properties often vary within some ranges. Therefore, the application of the adaptive ACS will improve the quality of control in cases when dynamic characteristics of executive and measuring devices are not stable.

Mathematical models of these elements can be represented as elementary dynamic units, whose dynamics are described by low order differential equations. The central task of this correction is the determination of the coefficients in these equations or corresponding transfer functions.

As an example of the solution within this task, an analysis of the characteristics of the temperature sensor (thermocouple) is carried out in the paper [12]. The analysis showed that the main focus of this direction is to ensure the required precision of the element's dynamic parameters determination. The responding speed of these elements is substantially longer than the characteristic time of the engine transients. The dynamic parameters of the element show a weak influence on the character of the transients, as the processes are quasi-static regarding the element. Low sensitivity determines a high level of identification errors.

This problem grows due to the fact that the engine and all elements operate in a closed-loop control system, which dynamics is limited not only by its own dynamic properties but also by limitations in the rate of the set values change in the Setting device (see Fig. 1) and also by programs of the engine acceleration/deceleration control.

Therefore, this adaptation loop will be effective only in case when the test actions on the elements are used. Grounding of character, intensity, and durability of these actions is a subject of individual researches. The paper [12] is the example of motion in this direction.

\section{ADAPTATION TO TECHNICAL STATE VARIATION OF MEASURING SYSTEM}

This type of adaptation is based on continuous monitoring of the technical state of the measuring channels based on comparing the measured values of the engine output parameters against the calculated values. For calculation, the model-based dynamic filtering algorithms are applied, e.g., Kalman filter.

The scheme for such system is shown in Fig. 6, examples of its realization are given in the papers [13-20].

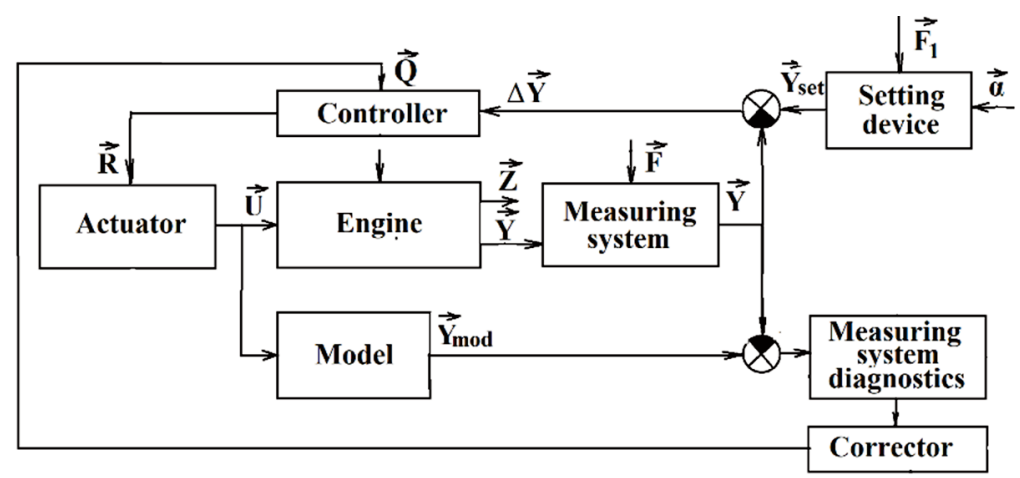

Fig. 6. ACS with correction on the measuring system condition.

When a fault is detected, corrective action will be generated. As a rule, this action consists of a replacement of the measured value of the parameter, which comes from the faulty channel, by a calculated value. Additionally, the possibility of an increment in the error of this parameter determination must be taken into account. For example, the proper correction of the set value must be made. Besides, an alternative solution is to block the channel that controls this parameter and switching the engine to a lowered operation mode. 


\section{CONCLUSION}

Hence, progress in on-board electronics stimulates a fast development in the adaptive automatic control systems of the aircraft turbine engines based on mathematical models.

There are created methodical bases for realization of all directions of adaptation: from the variation of operation mode and flight conditions to the individual features and technical state variation of the engine, actuators, and measuring system.

\section{REFERENCES}

[1] Rutkovskii, V.Yu., Ilyasov, B.G. and Kabalnov, Yu.S., 1995, Adaptive control systems of aircraft gas turbine engines, Moscow Aviation Institute, Moscow, 224 p.

[2] "Reference book on automatic control systems" / Edited by A.A. Krasovskii, 1987, Moscow, Science edition.

[3] Yepifanov, S., Kuznetsov B., Bogayenko, I. et. al., 1998, Synthesis of turbine engine control and diagnostics systems, Technical publishing, Kiev, Ukraine, 312 p.

[4] Jaw, L. and Mattingly, J., 2009, Aircraft engine controls: Design, system analysis, and health monitoring. American Institute of Aeronautics and Astronautics, Inc.: Reston, USA, 378 p.

[5] Saravanomuttoo, H.I.H., Rogers, G.F.C. and Cohen, H., 2001, Gas turbine theory. 5-th edition, Pearson Education Ltd., Edinburgh, England, 491 p.

[6] Kulagin, V.V., 2003, Theory and designing of aircraft engines and power plants. Book 1, 2, Mechanical Engineering Publishing, Moscow, 616 p.

[7] Litvinov, Yu. and Borovick, V., 1979, Performances and maintenance properties of aircraft turbine engines, Mechanical Engineering Publishing, Moscow, 288 p.

[8] Lyubomudrov, Yu.V., 1971. Application of similarity theory in designing of turbine engine automatic control systems, Mechanical Engineering Publishing, Moscow, 200 p.

[9] Volkov, D. and Yepifanov, S., 2005, „Coordination of ranges for turbine engine quasi-linear dynamic model setting at its piecewise linear representation”, Engine Engineering Gerald, V. 2, pp. 67-71.

[10] Zelenskyi, R., Yepifanov, S., Sirenko, F., Pasichnyk, S., 2017, „All-mode fast-response model of three-spool turbine engine with approximated coefficients of linear dynamic model”, Aerospace Technique and Technology, 9(144), pp. 109-118.

[11] Khustochka, A., Yepifanov, S., Zelenskii, R. and Przysowa, R., 2020, „Estimation of performance parameters of turbine engine components using experimental data in parametric uncertainty conditions", Aerospace, 7(1), 16 p.

[12] Yepifanov, S. and Li. Qijie, 2019, „Analysis of the error in the gas temperature and the thermocouple time constant measuring through gas turbine engine tests", Integrated Computer Technologies in Mechanical Engineering. Advances in Intelligent Systems and Computing, vol. 1113, Springer, Cham., pp.325-336.

[13] Kobayashi, T. and Simon, D.L., 2004, „Evaluation of an enhanced bank of Kalman filters for inflight aircraft engine sensor fault diagnostics”, ASME Turbo Expo Paper No GT2004-53640, Vienna, Austria.

[14] Viassolo, D., Aditya, Kumar and Brunell, B., 2007, „Advanced controls for fuel consumption and time-on-wing optimization in commercial aircraft engines", ASME Turbo Expo Paper No. GT2007-27214, Montreal, Canada.

[15] Simon, D.L., 2010, „An integrated architecture for on-board aircraft engine performance trend monitoring and gas path fault diagnostics", 57th Joint Army-Navy-NASA-Air Force (JANNAF) Propulsion Meeting, Colorado Springs, Colorado, NASA/TM-2010-216358. 
[16] Githanjali, B., Shobha, P., Ramprasad, K.S. and Venkataraju, K., 2006, „Full authority digital engine controller for marine gas turbine engine”, ASME Turbo Expo Paper No. GT2006-90439, Barselona, Spain.

[17] Kobayashi, T. and Simon, D. L., 2003, „Application of a bank of Kalman filters for aircraft engine fault diagnostics”, ASME Paper GT2003-38550.

[18] Aditya, Kumar and Viassolo, D., 2008, „Model-Based Fault Tolerant Control”. Tech. Rep. NASA/CR-2008-215273, NASA, USA.

[19] Feng, Lu, Jinquan Huang and Yaodong Xing, 2012, „Fault diagnostics for turbo-shaft engine sensors based on a simplified on-board model", Sensors, 12, 11061-11076.

[20] Csank, J.T. and Simon, D.L., 2013, „Sensor data qualification technique applied to gas turbine engines", Tech. Rep. NASA/TM-2013-216609, NASA, USA.

\title{
AUTOMATYCZNE STEROWANIE SILNIKIEM TURBINOWYM SAMOLOTU OPARTE NA DYNAMICZNYCH MODELACH ADAPTACYJNYCH
}

\begin{abstract}
Abstrakt
Jednym z najbardziej perspektywicznych kierunków rozwoju silnika lotniczego jest zastosowanie adaptacyjnych cyfrowych systemów automatycznego sterowania (ACS). Istotnym elementem adaptacji jest korekta modeli matematycznych zarówno silnika, jak i jego urządzeń wykonawczych oraz pomiarowych. Modele te pomagają rozwiązywać zadania sterowania i są połączeniem modeli statycznych i dynamicznych, ponieważ modele statyczne opisują relacje między parametrami w trybach ustalonych, a dynamiczne korygują odchylenia parametrów od wartości statycznych. W pracy rozważono problemy korekcji modeli z wykorzystaniem parametrycznych metod identyfikacji. Wykazano, że głównym problemem precyzyjnej symulacji silnika jest korekta modelu statycznego. W tym celu proponuje się procedurę opartą na szerokim zastosowaniu informacji a priori o osiągach silnika i jego układu pomiarowego. Jeden z wielu wariantów tej procedury przewiduje zastosowanie nieliniowego modelu termodynamicznego procesu pracy i oszacowanie poszczególnych poprawek charakterystyk elementów silnika z dalszym zastępowaniem modelu termodynamicznego przez aproksymację pokładowego modelu statycznego. Fizycznie uziemione oszacowania uzyskuje się na podstawie informacji a priori dotyczących oszacowanych parametrów i osiągów silnika, przy użyciu zbiorów rozmytych. Urządzenia wykonawcze (siłowniki) i najbardziej bezwładnościowe czujniki temperatury wymagają korekty ich modeli dynamicznych. Badania wykazały, że w przypadku, gdy dane do identyfikacji zbierane są podczas normalnej pracy ACS, oszacowania dynamicznych parametrów modelu mogą być silnie skorelowane, co powoduje niedopuszczalne błędy. Przyczyną są znaczne ograniczenia intensywności stanów nieustalonych, które zawierają regularne algorytmy sterowania przyspieszaniem / zwalnianiem. Dlatego wymagane są działania testowe na silniku. Ich charakter i minimalny skład określane są za pomocą wyprowadzonych relacji między błędami współczynników modelu, procesem pomiarowym i parametrami akcji kontrolnej.
\end{abstract}

Słowa kluczowe: silnik turbinowy, automatyka, model adaptacyjny. 